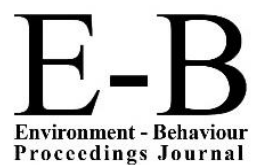

Environment - Behaviour
CSSR 2018

https://cssr.uitm.edu.my/2018/

5th International Conference on Science and Social Research

Le Meridien Kota Kinabalu Hotel, 5 - 6 December 2018

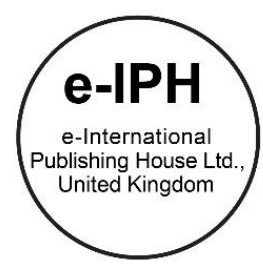

\title{
Since the Development of New Pattern of Minangkabau until the Motif Batik is Patented
}

\author{
Herwandi, M. Hum \\ Senior Lecturer, Faculty of Humanities, \\ Andalas University, Padang, Indonesia. \\ herwandi@hum.unand.ac.id \\ Tel: 006-281363435343
}

\begin{abstract}
The Minangkabau ethnic group is centred in the central highlands of the island of Sumatra. Minangkabau societies are matrilineal in descent and conceive of two customary (adat) philosophies. They are expressed as the ever-expanding world as an educator (Alam terkembang jadikan guru) and adat based on sharia, sharia-based on the Qur'an (adat basandi syarak, syarak basandi Kitabullah). These adat philosophies have produced hundreds of traditional decorative patterns. This study discusses on Minangkabau ornamental patterns. Their motifs and philosophical bases. This article addresses seven new ornate designs and seven batik motifs, which have been designed, patented and analyses their foundations in Minangkabau philosophy.
\end{abstract}

Keywords: Batik, Designs, Minangkabau, Motifs

eISSN: 2398-42870 2020. The Authors. Published for AMER ABRA cE-Bsby e-International Publishing House, Ltd., UK. This is an open access article under the CC BYNC-ND license (http://creativecommons.org/licenses/by-nc-nd/4.0/). Peer-review under responsibility of AMER (Association of Malaysian Environment-Behaviour Researchers), ABRA (Association of Behavioural Researchers on Asians) and cE-Bs (Centre for Environment-Behaviour Studies), Faculty of Architecture, Planning \& Surveying, Universiti Teknologi MARA, Malaysia.

DOI: https://doi.org/10.21834/ebpj.v5iSl3.2574

\subsection{Introduction}

The Minangkabau ethnic group in Indonesia is centred in the central highlands of Sumatra Island. In this area, many ancient prehistoric cultural artefacts are found, especially in the Lima Puluh Koto (fifth region). These cultural artefacts are the remnants of Neolithic-megalithic culture scattered in almost every traditional village in this area. Some of those cultural artefacts strongly indicated and correlated with initial reconstruction, the origin of Minangkabau culture (Herwandi, 2007). The explanation is also about the archaeological remains found reflected some elements of traditional Minangkabau culture had been sown at that time. Some aspects of Minangkabau culture have been practised in the prehistoric period, including decorative art developed today. The origin of Minangkabau decorative art has emerged from prehistoric times since the Neolithic-megalithic period. Until now, it stated that the history of the Minangkabau ornamental pattern has already a long history (Herwandi, 2010; 2011; 2013; Nizar, 1986).

Currently, people's appreciation of the traditional design of Minangkabau decorative patterns does not fade away. Still, it starts to decline, due to the possibility of high pricing, and the fact that the number of people possessing expertise in this field has been increasingly scarce. However, these decorative patterns are often found in traditional artefacts and buildings, menhirs, gravestones, and other artistic objects. Unfortunately, most of these artistic artefacts and old buildings have suffered a lot of damages (Herwandi,

eISSN: 2398-4287@ 2020. The Authors. Published for AMER ABRA cE-Bsby e-International Publishing House, Ltd., UK. This is an open access article under the CC BYNC-ND license (http://creativecommons.org/licenses/by-nc-nd/4.0/). Peer-review under responsibility of AMER (Association of Malaysian Environment-Behaviour Researchers), ABRA (Association of Behavioural Researchers on Asians) and cE-Bs (Centre for Environment-Behaviour Studies), Faculty of Architecture, Planning \& Surveying, Universiti Teknologi MARA, Malaysia. DOI: https://doi.org/10.21834/ebpj.v5iSI3.2574 
2011). Nowadays, the batik industry in Minangkabau is increasingly growing. Generally, batik artisans have been adopting traditional decorative patterns to decorate fabrics. Unfortunately, of all the craftsmen, some of them produce batik motifs ignore classical philosophy, resulting in countless products of batik motifs that do not reflect the Minangkabau traditional philosophy.

\subsection{Literature Review: Relationship Between Art, Culture, And Society}

Art and Culture is one of the benchmarks of a civilisation status(Kusrianto, 2002), wherever art appears. Art has an inseparable connection with its own culture and society (Sedyawati \& Damono, 1982) because art is part of the cultural element (Sumardjo, 2007; Haryono, 2009). The study of art (art history, particularly) ought to be viewed as an integral unity, intertwined with the dynamics of the problem in a society at any given time and place (Hauser 1957). The variety of Minangkabau traditional decoration, as a product of art, grows and develops in parallel with the dynamics and symptoms that occur within the community (Herwandi 2011, 2013). Therefore, every art development during its own time possesses a character or soul of that particular time (zeitgeist). The soul of the time is very closely related to the nature and unity of the art style that lies behind the birth and development of art in society (Wolfflin, 1929). If associated with the development of the art of Minangkabau ornamental patterns, it is closely related to the ongoing changes following the evolution of society.

\subsection{Methodology}

In this research, it combines archaeological and historical perspective research, which will examine the artefacts and ornate buildings that exist in Minangkabau, as well as documents and literature that can be used as data sources in this study. The stage of observation and data collection involved library and field research. Library research is directed to collect sources of data from books and similar sources. The field research carried out, where a direct examination of decorative artefacts, inventory and documentation of decorative patterns is encountered and made, which particularly on several menhirs, tombstones, and traditional buildings, such as traditional adat houses, traditional meeting halls, surau, and masajid (mosque) at traditional Minangkabau villages. Then an attempt was made to revitalise the decorations by creating a new motif. The revitalisation and creation of new ornamental patterns lead to the birth of new decorative design. Later the motif developed into several batik designs. Each design will be registered at the Ministry of Justice and Human Rights of the Republic of Indonesia to obtain legitimate ownership or copyright certification (patent).

\subsection{Findings: Minangkabau Decorative Patterns}

Herwandi $(2003 ; 2011 ; 2013)$ explained that the art of decoration in Minangkabau has started since prehistoric, precisely in the neolithic-megalithic period. Some ornamental patterns that are found today have already existed in ancient times. Especially during the megalithic tradition period. The developed-in Lima Puluh Kotocan id found in the motifs of tendrils in the form of kaluanails, roots, and triangular motifs. The ornamental silk (a piece) galamai (galamai is one small food based on glutinous rice flour) and wajik. Wajik is the traditional snack of diamond-shaped, sticky rice and other ingredients to sweeten it (Herwandi,1984; 2003; 2007; 2011; 2013). Then, the decorative patterns were developed during the Buddhist era, which naturally paved the way for many new decorative patterns to emerge. The decorative designs are thought to appear in this era, include the pattern of roots and leaves, such as "bungo taratai di aie" (lotus flowers floating and growing in water), "bungo bodi" (bodhi flowers), "kipeh cino" (Chinese fan), Bodi Leaves ("Daun Bodi") "Body Leaf and Kipeh Cino" (bodi leaves and Chinese Fan). The lotus flowers grow in water, have their roots grow in the water, while the leaves surface over the water and its flowers blossom into the open air. In Buddhism, the lotus is considered to be a sacred plant that is favoured by the gods. While bodi leaves are an abstract depiction of the leaves of the body tree under which Buddha meditates. Here, then we have Chine hand-fan ("Kipeh Cino"), or Chine roots ("aka cino,").

They all present the influence of Chinese culture in Minangkabau ornamental patterns. The influence Chinese decorative patterns are also expected to enter into Minangkabau land during the Buddhist era. Nowadays, the ornament of artefacts and art objects in Minangkabau have developed decorative designs in the Neolithic-megalithic period and the Buddhist age. Still, the decorative patterns that have emerged have been influenced by Islamic art philosophy. Minangkabau traditional decorative patterns are dominated by patterns of leaves, flowers, roots, as well as in ornamental of the Islamic world. In the previous article, Herwandi suggests that the pattern of animal ornaments is not painted in real life shapes. Even if there is an attempt to describe the form of living things and animals, its description is always abstract, disguised in the ways of roots, leaves, and flowers. Therefore, it is not surprising that Minangkabau ornamental patterns are still dominated by foliage, roots, and flower forms, but many are named after specific animals, it happens due to the influence and facility of strong Islamic arts (Herwandi, 2011; 2013). In the art of Islam, decorative patterns that are prominent also dominated by the pattern of foliage and geometric, are abstract, which avoid the depiction of living things (Grabar, 1973, al-Faruqi, 1999). This shows how Islam has influenced the art life of the Minangkabau community (Herwandi, 2011; 2013). Marah (1988) has done the grouping of Minangkabau ornamental pattern names into three categories or large groups, and they are motifs derived from the names of plants, animals, and inanimate objects, people, and others. As a result, 153 Minangkabau ornamental patterns available in Minangkabau artistic artefacts were identified. Based on the accomplishment of the grouping that Marah performed, out of 153 decorative designs, 69 motifs are classified into the name of plants, 40 motifs are attributed to animals, and 44 motifs belong to the name of inanimate objects, while the remaining are organised into a different group (Herwandi, 2011; 2013). 


\subsection{Discussion: Basic Foundation for The Creation of New Decorative Patterns and Designs of Batik Motifs to be Patented}

\subsection{The Base of Traditional Foundation}

The art world in Minangkabau is, at the bare minimum, based on vertical and horizontal foundation or ground. The vertical foundation is the religion and religious values that develop, while the horizontal foundation is the surrounding natural phenomena and social benefits where Minangkabau people live. In this case, the foundation is outlined in the customary credo "Adat basandi syarak, syarak basandi Kitabullah" (Custom is based on syari'ah law, and syari'ah law derives from Al Qur'an). In contrast, the horizontal foundation is the social values that develop in society and surrounding nature or environment, as formulated in the customary credo "Alam takambang jadi guru" (the vast nature is the best teacher) (Navis 1896, 59; Nizar 2003). Therefore, every work of art, including Minangkabau ornamental patterns, which have always been inspired by the surrounding nature in which the art takes place, and every activity of art is still based on the joints of Islam, gives birth to Islamic art (Herwandi, 2011; 2013).

\subsection{Designing New Islamic Decorative Patterns and Patents}

In developing creative industries in Minangkabau, a number of design activities have been performed. The activity is revitalising traditional decorations by making new motifs. These activities have spawned a number of new decorative patterns that do not contradict the foundation of traditional and Islamic arts. These motifs maintain the abstract nature as reflected in other Islamic decorative arts. The design of these new decorative patterns has materialised in the forms of batik motifs that will be beneficial for creative forms of batik industry in West Sumatra. Some of these new motifs have been granted with copyrights and patents from the Ministry of Justice and Human Rights of the Indonesian Republic. Until now, dozens of copyright or patent certificates have been obtained. For example, the following are four motifs that have been recognised and awarded with patent rights from the Ministry of Justice and Human Rights of the Indonesian Republic: 1) Kabek Daun Kacang (Bean Leaves Binder); 2) Garundang Mandi (Bathing Tadpole);3) Ayam Balatiang (Cockfight); 4) Ayam Jantan (Rooster). The following descriptions of each pattern of ornaments and motifs that have been designed for the revitalisation of Minangkabau traditional decoration. The following description is specific to the design of patented motifs only.

\subsubsection{Peanut Leaves Binder Motif}

Peanut is a plant that is very familiar to the Minangkabau community since people generally plant nuts in their gardens. The peanut leaf binder motif is an abstract depiction of peanut leaves orderly arranged and tied with a binder. In Minangkabau culture, there are many terms and proverbs linked to bean and often used in daily life. For example, as in "Lupo kacang jo kuliknyo," and "Kacang diabuih ciek". The term "Lupo kacang jo kuliknyo" commonly used for people who usually forget the services of others who once have helped her (Syaidam, 2009b). Those terms are as an allusion to the apparent inequities arising in society. Just as the term beans are, "diabuih ciek" (like out of countless beans but only one bean is boiled) if only one single peanut is boiled, there is only one peanut in the pot.

Consequently, it will bounce alone, nothing else. It is used by the Minangkabau community to show how a person feels more important than everyone else. Other people are considered unlike him. He is more than anything else compared to others, and no one is at the same level as him/her.

The term Kabek daun kacang (peanut leave binder) is used to refer to the name of this decorative pattern. These following decorative motifs do not reflect similar negative attitudes as the previous two described earlier. Philosophically, the Kabek daun kacang precisely demonstrates the existence of a simple, neat, and disciplined arrangement complimented filled with a soothing beauty. Peanut leaves motif is a reflection of a simple society, a very well structured, subject to the rules of the civil society, with clarity, and disciplined in observing such rules that have been agreed together. Peanut leaves binder motif is showing the element of modest (rural area) communities in Minangkabau. Who adheres themselves to a customary philosophy of "Adat basandi syarak, syarak basandi Kitabullah, syarak mangato adat mamakai" (Adat bersendikan hukum syarak, syarak bersendi Al-Quran, sharia determines, and the custom implies it)?

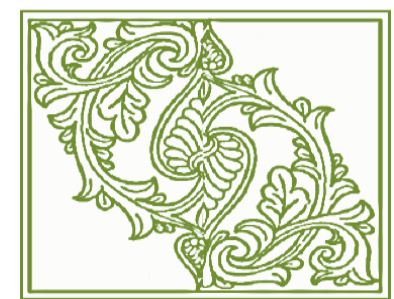

Figure 5.1: Design of Bean Leaves Binder Motif. (Designed by Herwandi, 2016).

This design has then been developed into a batik motif, which goes by the name Bean Leaves Batik Motif. This motif of batik has been "patented," registered with the Ministry of Law and Human Rights Office of the Republic of Indonesia and is recorded with copyright registration certificate No. EC00201702467. This batik motif has been produced as depicted in the following figures. 


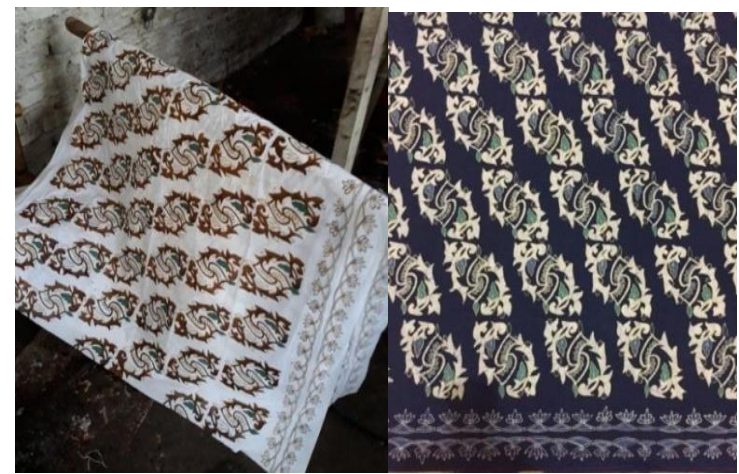

Figure 5.2: The Design of Bean Leaves Binder Batik Motif that has been produced in the form of handmade.

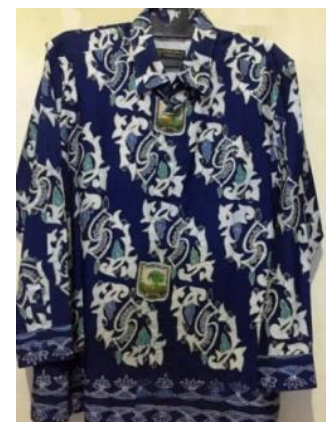

Figure 5.3: Design of Bean Leaves Binder Batik Motif that has been produced into ready-to-wear batik shirt.

\subsection{2. "Garundang Bathing" Motif}

Garundang Mandi Motif is one that describes an abstract motif of a group of tadpoles offsprings. Garundang is a term used by the Minangkabau community for tadpoles offsprings (Syaidam, 2009a). In Minangkabau cultural vocabulary, there are several terms associated with garundang, such as gadang garundang di kubangan (Syaidam, 2009b). The term gadang garundang di kubangan (big tadpole in backwater), is a term that describes that the habitat of garundang usually found in buffalo puddles with an inadequate amount of water. This reflects that garundang represents a small community, living in small "habitat," but they preferred to live in togetherness. Togetherness is the strength, as well as the beauty of their lives. A little while, the garundang continue living and grow big in the backwater. Thus, the saying Gadang garundang di kubangan will mean that garundang shall have their might in their habitat. This reflects that one will acquire his/her dignity within his community; if he/she is living among the people who do not recognise him, he remains an ordinary person.

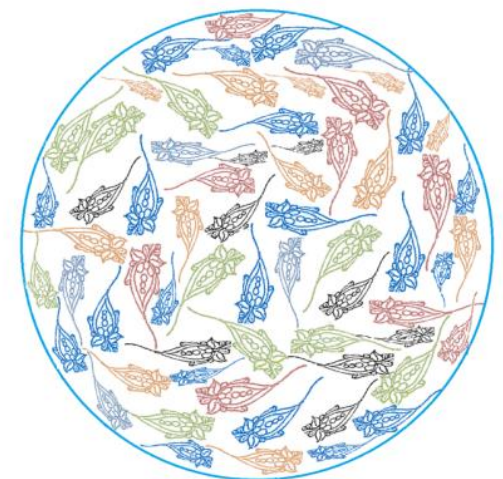

Figure 5.4: The design of Garundang Bathing Motif. (Designed by Herwandi, 2016).

This design has also been developed into a batik motif, which is named Garundang Mandi batik motif. The batik motif of Garundang Mandi has also been "patented," and registered with the Ministry of Law and Human Rights of the Republic of Indonesia and is recorded with copyright registration certificate No. EC00201702470. This batik motif has been produced (made available for a price) as displayed in the following pictures. 


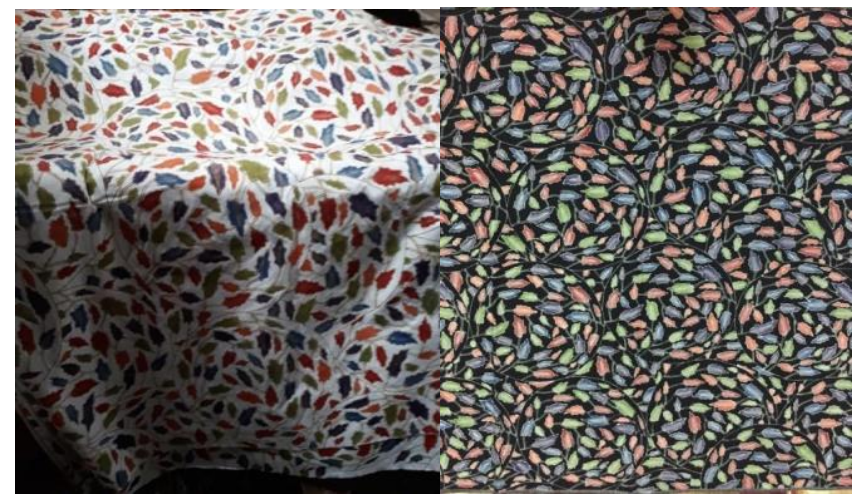

Figure 5.5: The design of Garundang Mandi Tadpoles, produced in the form of handmade batik cloth

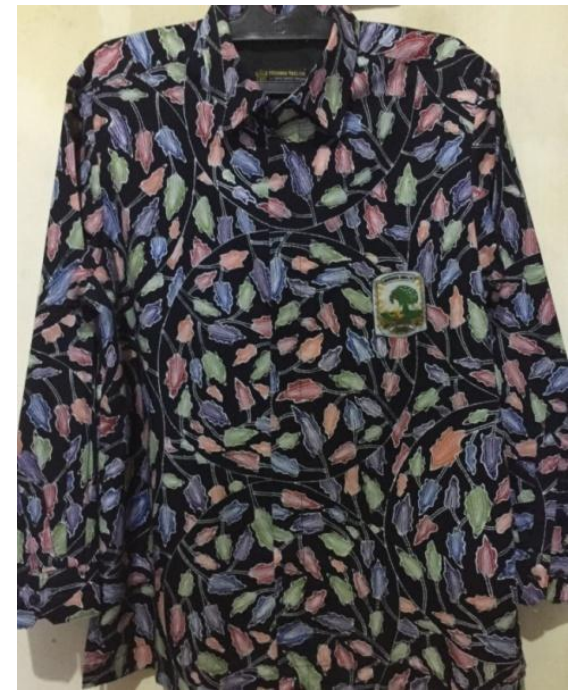

Figure 5.6: The design of Garundang Mandi, produced in the form of ready-to-wear batik shirt

\subsection{3. "Cock Fight" Motif}

Ayam ballating motif is an abstract depiction of two cocks that are fighting. In the vocabulary of Minangkabau culture, there is a tradition of cockfighting that is deliberately done to put the chicken for the chicken fights until one chicken is defeated. Sometimes the chickens to be pitted are given a spurs blade mounted on the chicken's heels. It is also frequent that cockfight involved by shamanism (magic). The term Ayam balatiang may be used as a substitute for events of certain sports activities and competition between political contestants. Philosophically, the term Ayam balatiang reflects the meaning associated with competition in life. Life is full of competition, loaded with competition and fighting. The victory shall belong to the strong and the cunning in this life's dynamics.

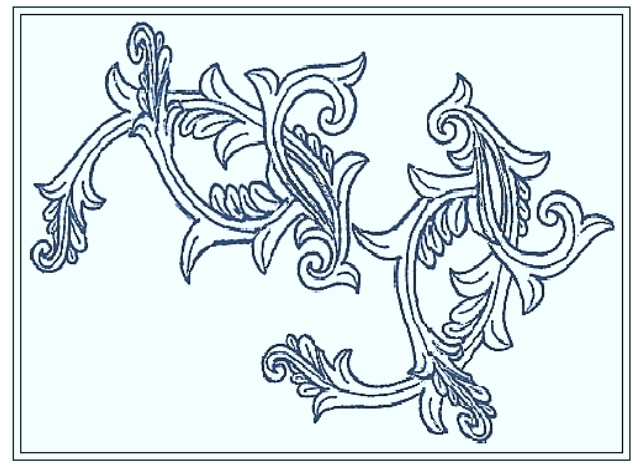

Figure 5.7: The design of the Ayam Balatiang Motif (Designed by Herwandi, 2016).

This design has also been developed into a batik motif by the name Ayam Balatiang batik motif. The batik motif of Ayam Balatiang has also been "patented," registered with the Ministry of Law and Human Rights of the Republic of Indonesia and is recorded with copyright registration certificate No. EC00201704588. This batik motif has been produced (available for a price), as displayed below. 


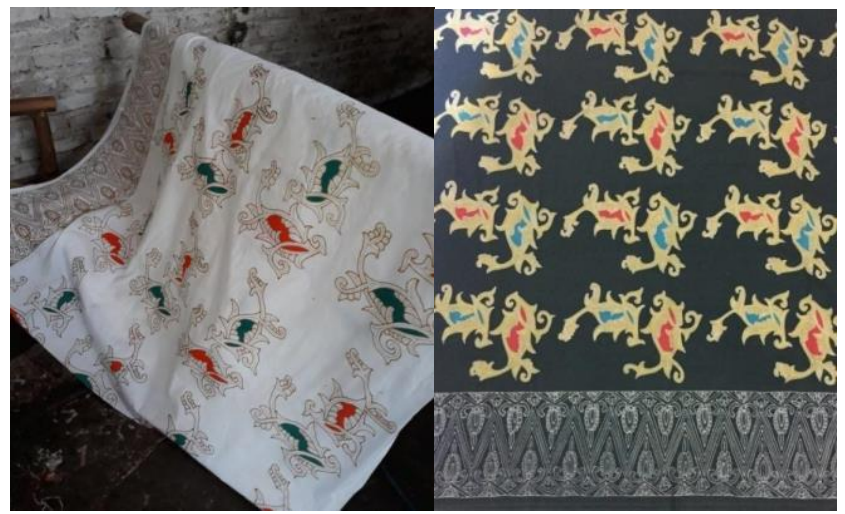

Figure 5.8: The design of Ayam balatiang Batik Motif that has been produced ion a form of batik fabric.

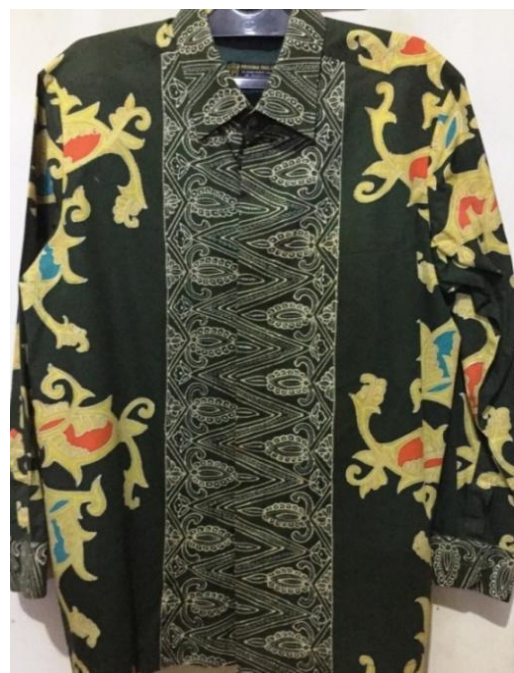

Figure 5.9: The design of Ayam balatiang Batik Motif, which has been produced in ready-to-wear Batik form rooster motif is an abstract depiction of a rooster, or commonly also called a rooster (Syaidam, 2004).

\subsubsection{Rooster Motif}

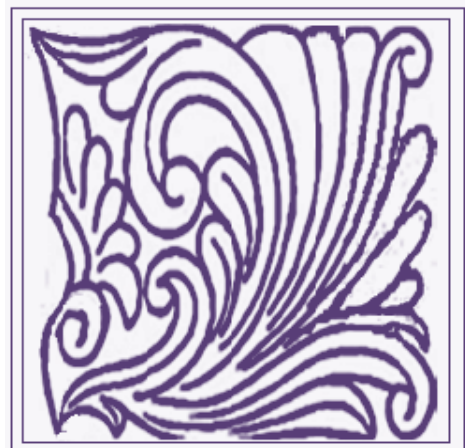

Figure 5.10: The design of the Ayam Jantan/Rooster Motif. (Designed by Herwandi, 2016)

This design has also been developed into a batik motif, which is named Unand-Ayam Jantan batik motif (Andalas University Rooster Batik Motif). The Unand-Ayam Jantan batik motif has also been "patented," registered with the Ministry of Law and Human Rights of the Republic of Indonesia and recorded under a copyright registration certificate No. EC00201704585. The term Unand in naming the motif of "Unand Ayam Jantan" is a well-known university in Indonesia, located in West Sumatra. Andalas University ('Unand' for short) has become the educational pride of learning institution for Minangkabau people, as the icon of higher education forefront in the area. The motif of "Unand-ayam Jantan" as a symbol of roosters, the pride of Minangkabau people in the field of education in Indonesia. This batik motif has been produced as shown in the following 


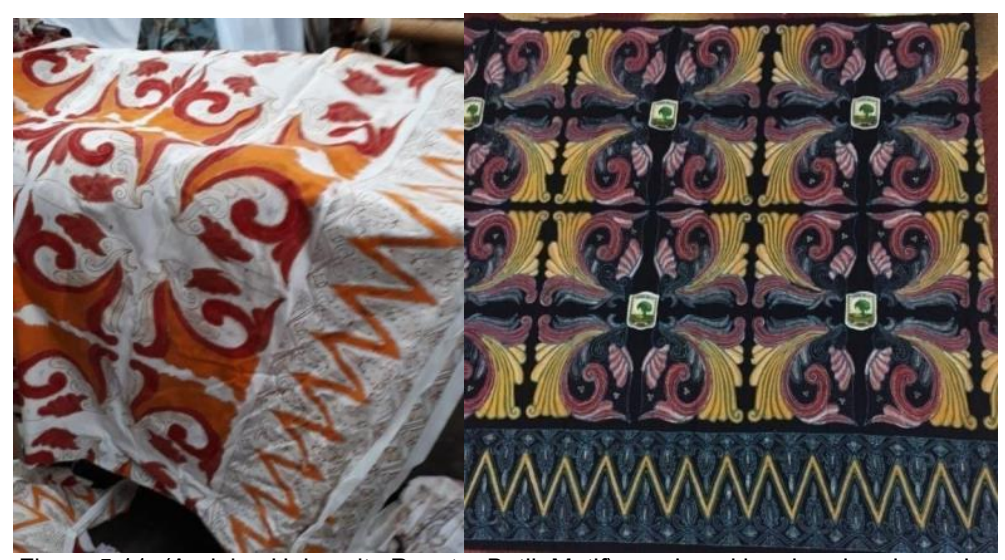

Figure 5.11: (Andalas University Rooster Batik Motif), produced in a handmade mode.

\section{Conclusion and Recommendations}

Ideally, the Minangkabau ornamental pattern is abstract and prohibits depictions of animals in detail. This has a resemblance to what is expressed in the art of Islam. Islamic art also nourishes the foliage, geometric and abstract decorative pattern of ornament. It is recommended that training be given to existing batik designers to be trained in order to make motifs in accordance with the Minangkabau traditional philosophy. This must be done so that there are no more designers who make batik that runs from indigenous philosophy.

\section{Acknowledgements}

This article is the result of research funded by the research scheme of Andalas University, Padang, in compliance with Research Implementation Agreement No. 524/XIV/A/UNAND- 2016.

\section{References}

Arnold, H. (1957). The Social History of Art. I. New York: Al Fread A. Knopf. Inc.

Al-Faruqi, I. R., \& Hadikusumo, H. (1999). Seni Tauhid: Esensi dan Ekspresi Estetika Islam. Yayasan Bentang Budaya.

Edward, J. (1991). Tambo Minangkabau: Suntingan Teks Disertai Analisis Struktur. Jakarta: Balai Pustaka.

Grabar, O. (1973). The Formation of Islamic Art. New Haven dan London: Yale University Press.

Haryono, T. (2009). Seni dalam Dimensi Bentuk, Ruang, dan Waktu. Jakarta: Wedatama Widya Sastra.

Herwandi (1994). "Nisan-Nisan di Situs Mejan Tinggi, Desa Talago Gunung, Kabupaten Tanah Datar, Sumatera Barat: Kajian tentang Kelanjutan Budaya Tradisi Megalitik ke Budaya Islam". Master's Thesis. Jakarta: Univ. Indonesia. 1994.

Herwandi (2003). "Menhir dan Akar Budaya Pola Hias Minangkabau”. In Jurnal Kabudayaan. Pascasarjana Udayana. Bali.

Herwandi dan Zayardam (2007). Menggugat Minangkabau. Padang: PSH.

Herwandi (2011)"Sentuhan Islam dalam Pola Hias Minangkabau: Sebuah Tinjauan Etnoarkeologis". Paper, presented at the "International Seminar on IndonesianMalaysian Relations" on July 12-14, 2011, at the Faculty of Art and Social Sciences, Malaya University, Kuala Lumpur, Malaysia.

Herwandi (2013) "Yang Baru dan Yang Ingkar: Pola Hias Minanagkabau yang lari ari Filosofi Adatnya', Paper presented at the "International Seminar on IndonesianMalaysian Relations" on October 22-24, 2013 at the Faculty of Arts and Social Sciences, University Malaya, Kuala Lumpur, Malaysia.

Kusrianto, Adi, K. \& Arini, M. (2011). History of Art. Jakarta: Kompas Gramedia.

Marah, R. (1973). Ragam Hias Minangkabau. Jakarta: Depdikbud.

Navis, A. A. (1986). Alam Terkembang Jadi Guru: Adat dan Kebudayaan Minangkabau. Jakarta: Grafiti Press.

Nizar, H. (2003). Reaktualisasi Aadat Basandi Syarak, Syarak Basandi Kita Bullah (Kumpulan Makalah). Padang: Pusat Pengkajian Islam dan Minangkabau (PPIM) Sumatera Barat.

Nizar, H. (1986). "Menhir Berhias dari Situs Megalitik Limapuluh Koto Sumatera Barat". Bachelor Thesis. Jakarta: Universitas Indonesia. 
Hum, H.M., CSSR2018, 5th International Conference on Science and Social Research, Le Meridien Kota Kinabalu Hotel, 5 - 6 Dec 2018, E-BPJ, 5(SI3), Dec 2020 (pp.327-334)

Saydam, G. (2004a). Kamus Lengkap Bahasa Minang (Indonesia - Minang) Bagian Pertama. Padang: Pusat Pengkajian Islam dan Minangkabau (PPIM) Sumatra Barat.

Saydam, G. (2004b). Kamus Lengkap Bahasa Minang (Indonesia - Minang) Bagian Kedua. Padang: Pusat Pengkajian Islam dan Minangkabau (PPIM) Sumatra Barat.

Sedyawati, E. \& Sapardi D. D. (1983). Beberapa Masalah Perkembangan Kesenian Indonesia Dewasa Ini. Jakarta: UI.

Wolfflin, H. (1929). Principles of Art History: The Problem of Development of Style in Later Art. Terj. M.D. Hottinger. New York: Dover Publication Inc. 